\title{
Paleoseismology of silent faults in the Central Apennines (Italy): the Campo Imperatore Fault (Gran Sasso Range Fault System)
}

\author{
Fabrizio Galadini $\left({ }^{1}\right)$, Paolo Galli $\left({ }^{2}\right)$ and Marco Moro $\left({ }^{3}\right)$ \\ (') Istituto di Geologia Ambientale e Geoingegneria, CNR, Roma, Italy \\ $\left(^{2}\right)$ Servizio Sismico Nazionale, DPC, Roma, Italy \\ $\left({ }^{3}\right)$ Istituto Nazionale di Geofisica e Vulcanologia, Roma, Italy
}

\begin{abstract}
Paleoseismological analyses were performed along the Campo Imperatore Fault (part of the Gran Sasso Range Fault System) in order to define the seismogenic behaviour (recurrence interval for surface faulting events, elapsed time since the last activation, maximum expected magnitude). Four trenches were excavated across secondary faults which are related to the main fault zone. The youngest event (E1) occurred after 3480-3400 years BP; a previous event (E2) occurred between 7155-7120/7035-6790 years BP and 5590-5565/5545-5475 years BP, while the oldest one (E3) has a Late Pleistocene age. The chronological interval between the last two displacement events ranges between 1995 and 6405 years. The minimum elapsed time since the last activation is 800 years, due to the absence of historical earthquakes which may have been caused by the Campo Imperatore Fault and based on the completeness of the historical catalogues for the large magnitude events in the last eight centuries. Based on the length of the fault surficial expression, earthquakes with $M 6.95$ may be expected from the activation of the entire Gran Sasso Range Fault System. The effects of the fault activation were investigated through the simulation of a damage scenario obtained by means of the FaCES computer code, made by the National Seismic Survey for civil protection purposes. The damage scenario shows that the activation of the Gran Sasso Range Fault System may be responsible for an earthquake with epicentral intensity $I_{0} 10.5$ MCS, with a number of collapsed buildings ranging between 7900 and 31100 and a number of damaged buildings ranging between 99000 and 234000. The investigated case defines, therefore, a high risk level for the region affected by the Campo Imperatore Fault.
\end{abstract}

Key words paleoseismology - active fault - HoloceneCentral Italy

\section{Introduction}

Most of the available structural frameworks of the Abruzzi Apennines related to the present tectonic regime show that faults active

Mailing address: Dr. Fabrizio Galadini, Istituto di Geologia Ambientale e Geoingegneria, Area della Ricerca di Roma «Tor Vergata», Via del Fosso del Cavaliere 100, 00133 Roma, Italy; e-mail: f.galadini@igag.cnr.it during the Late Pleistocene-Holocene are organised in two different fault sets roughly trending NW-SE (Barchi et al., 2000; Galadini and Galli, 2000; D'Addezio et al., 2001; Valensise and Pantosti, 2001). Paleoseismological data (e.g., Pantosti et al., 1996) and the comparison between the active faulting framework and the distribution of the strong historical seismicity $(M \geq 6.5 ;$ e.g., from Working Group CPTI, 1999) show that almost all the faults of the western set activated during the 2nd millennium A.D. (Galadini and Galli, 2000). The same data, in contrast, indicate the lack of recent activation for most of 
the faults of the eastern set. The elapsed time since the last activation may be, in such cases, larger than 1000 years and for this reason these faults have been defined as silent by Galadini and Galli (2000). For example, in the case of the Mt. Morrone Fault an elapsed time of about 1800 years has been hypothesized (Galadini and Galli, 2001).

Considering that the recurrence interval per fault in the Abruzzi Apennines is in the order of 1500-2500 years, a high level of seismic hazard may be related to the faults of the eastern set (e.g., Peruzza and Pace, 2002). The Campo Imperatore Fault, which is part of the longer Gran Sasso Range Fault System, is one of the structures forming the eastern fault set. Paleoseismological investigations therefore seem appropriate to ascertain the fault activity and to define the fault behaviour.

This paper deals with paleoseismological investigations along the Campo Imperatore fault, made through the excavation and analysis of four trenches. Investigations were made during 1999. The Campo Imperatore Fault was partially investigated in the early 90 s by means of two trenches along its westernmost portion (Giraudi and Frezzotti, 1995). We tried to increase the data set on this fault by further trenching in the central portion. Preliminary results of the paleoseismological analysis along the Campo Imperatore Fault have already been published in a short note (Galli et al., 2002a). In the present paper, we intend to give a complete account of our paleoseismological analyses related to this fault.

After a short introduction on the seismotectonic framework of the Abruzzi Apennines, the following sections will be dedicated to the description and interpretation of the three most significant trenches. Implications of the analysis, in terms of fault behaviour (recurrence interval for surface faulting events, elapsed time, maximum expected magnitude) will be described in detail. A final section will be dedicated to the effects of the fault activation, in terms of damage in the territory surrounding the Gran Sasso Range Fault System. Although the investigated fault affects a high mountainous region, numerous villages and towns with maximum 100000 inhabitants are located in the hangingwall area and at a distance not further than $15 \mathrm{~km}$ from the fault surficial expression. The produced damage scenario will show that the activation of the investigated silent fault may have a destructive impact on a large portion of Central Italy.

\section{Active tectonic framework}

\subsection{The Abruzzi Apennines}

The Abruzzi Apennines have been affected by normal and normal oblique faulting during the Quaternary (e.g., CNR-PFG, 1987), synchronous to the regional uplift (e.g., D'Agostino et al., 2001) and the E-ward thrust migration in the Adriatic area (e.g., Patacca et al., 1990). Quaternary normal fault activity has been documented in a number of papers dealing with neotectonics (e.g. Cavinato, 1993; Galadini and Messina, 1994; Carrara et al., 1995). The main Quaternary faults generally border intermontane basins, filled by Plio-Quaternary lacustrine and alluvial deposits, showing geometric characteristics typical of the half-graben depressions. Persistent activity during the Late Pleistocene-Holocene can be derived from works dealing with paleoseismology (Pantosti et al., 1996; Galadini and Galli, 1999; D'Addezio et al., 2001) and active tectonics (Barchi et al., 2000; Galadini and Galli, 2000). Moreover, available seismic catalogues (e.g., Working Group CPTI, 1999) show that the investigated area has been struck by six events with $M>6.5$ since the 14 th century (i.e. the 1349, 1456, 1703 January 14, 1703 February 2, 1706, 1915 earthquakes).

The structural framework related to the present tectonic regime (fig. 1) shows that the Abruzzi Apennines are affected by two sets of NW-SE to N-S trending normal faults, as reported in most of the available works on paleoseismology and active tectonics (Barchi et al., 2000; Galadini and Galli, 2000; D'Addezio et al., 2001; Valensise and Pantosti, 2001). Paleoseismological and historical data suggest that almost all the faults of the western fault set activated during the 2nd 


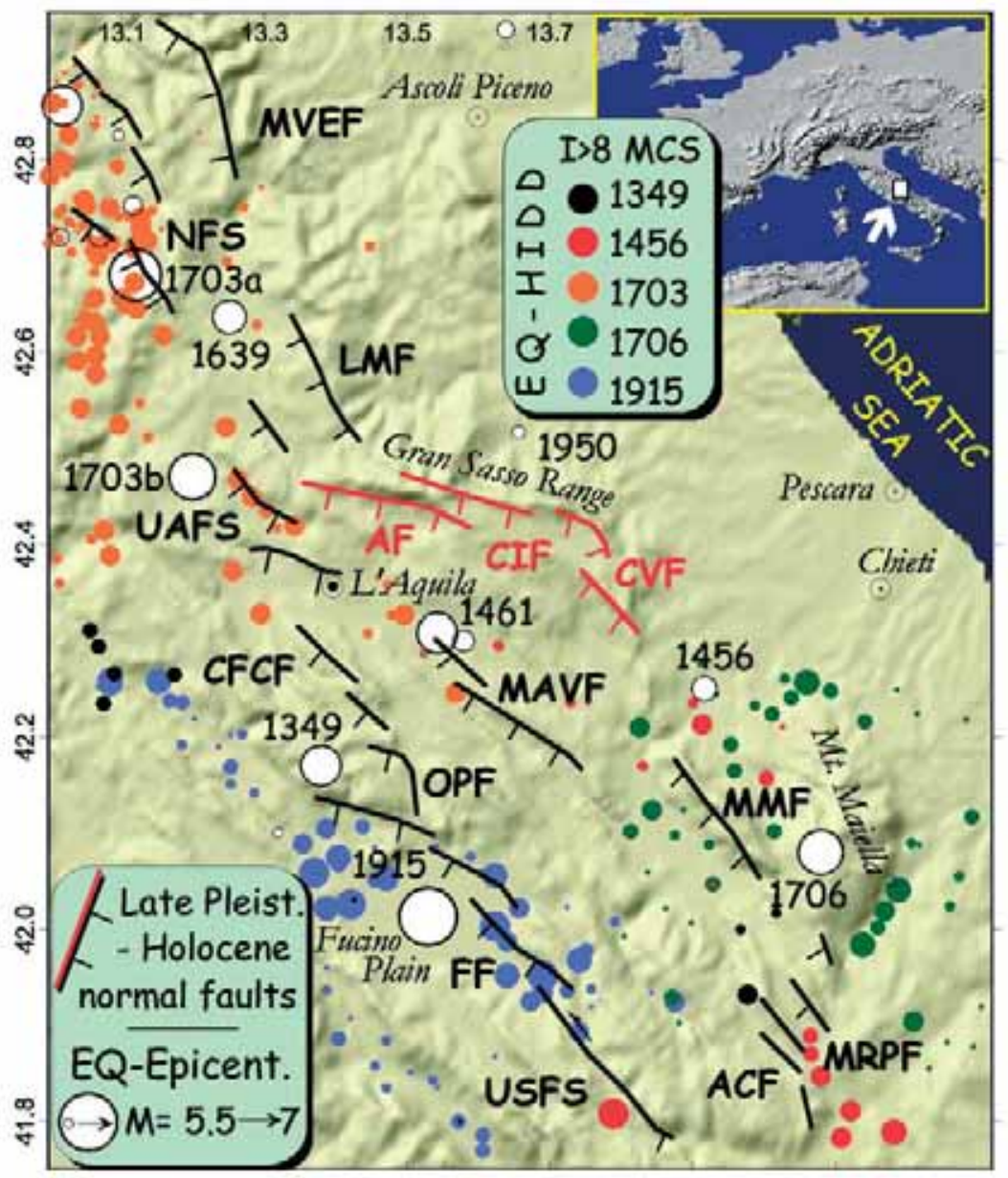

Fig. 1. Seismotectonic framework of the investigated area. The investigated faults are reported in red. Earthquake epicenters and the Highest Intensity Datapoints Distribution (HIDD; size proportional to intensity, $I>8 \mathrm{MCS}$ ) have been taken from Magri and Molin (1984) for the 1456 earthquake, Boschi et al. (1995) for the 1349 and 1706 earthquakes, Monachesi and Stucchi (1998) for the 1703 earthquake, Molin et al. (1999) for the 1915 earthquake; all the epicenter locations have been derived from Working Group CPTI (1999). MVEF - Mt. Vettore Fault; NFS - Norcia Fault System; LMF - Laga Mts. Fault; UAFS - Upper Aterno Valley Fault System; AF - Assergi Fault; CIF - Campo Imperatore Fault; CVF - Mt. Cappucciata-Mt. San Vito Fault; CFCF - Campo Felice-Colle Cerasitto Fault; MAVF Middle Aterno Valley Fault; OPF - Ovindoli-Pezza Fault; MMF - Mt. Morrone Fault; FF - Fucino Fault; MRPF - Mt. Rotella-Mt. Pizzalto Fault; ACF - Aremogna-Cinquemiglia Fault; USFS - Upper Sangro Valley Fault System.

millennium A.D., while there is no evidence of recent activation for most of the faults related to the eastern set (Galadini and Galli, 2000). The latter authors defined these faults (including the Campo Imperatore Fault) as silent.

\subsection{The Gran Sasso Chain - Campo Imperatore Plain}

The Gran Sasso Range area is affected by three main fault systems (from west: Assergi, Campo Imperatore and Mt. Cappucciata - Mt. 


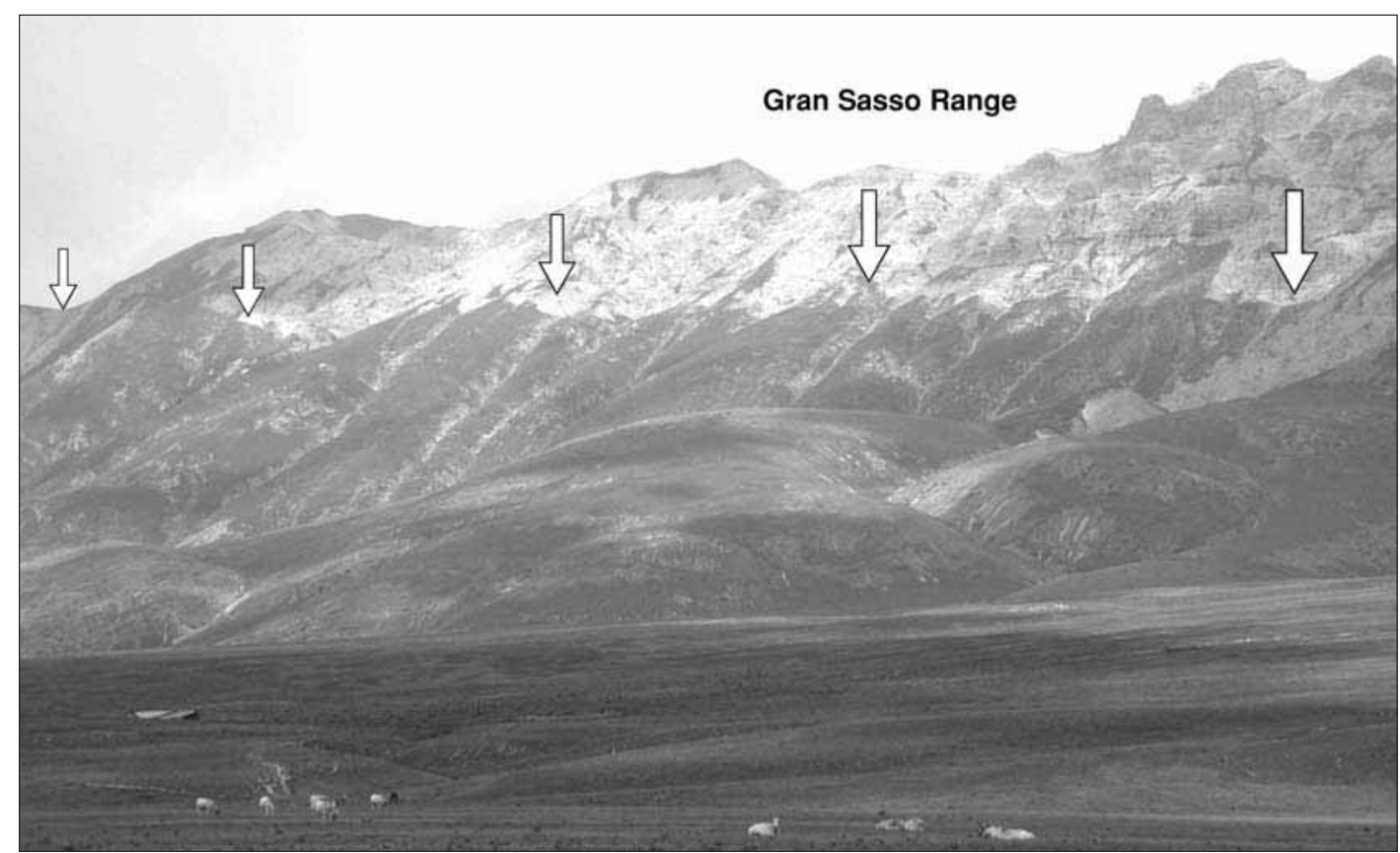

Fig. 2. View of the Campo Imperatore Plain and of the southern slope of the Gran Sasso Range; arrows mark the position of the bedrock scarp related to the main fault; trenches have been excavated across minor faults located in the large alluvial fan in the foreground (see next figures for further details).

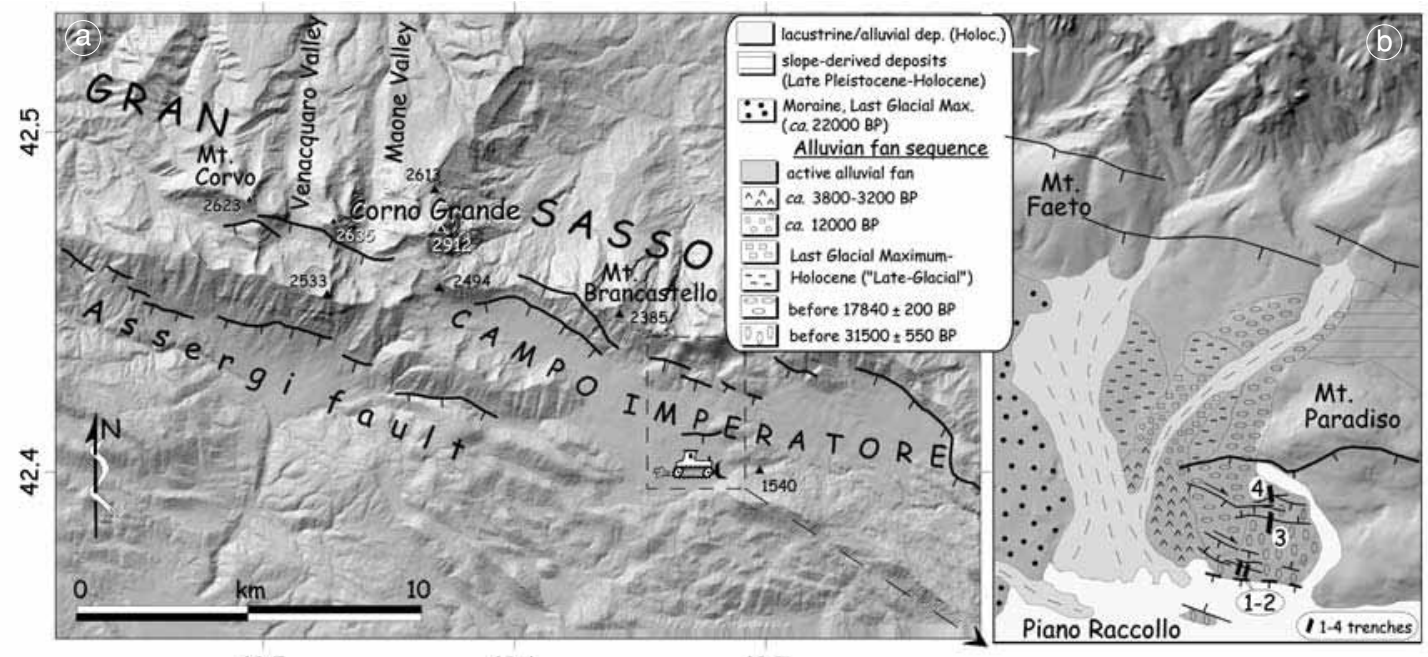

13.5

13.6

13.7

Fig. 3a,b. a) Plan map showing the faults of the Gran Sasso Range area characterised by Late PleistoceneHolocene activity. b) Geomorphological map of the Mt. Paradiso area and location of the trench sites. 
San Vito faults, respectively) showing evidence of Late Pleistocene-Holocene activity (Galadini and Galli, 2000; fig. 1). We investigated the central fault, N120-130 trending and $21.5 \mathrm{~km}$ long, which bounds the Campo Imperatore Plain (figs. 1, 2 and $3 \mathrm{a}, \mathrm{b})$. This basin is filled by glacial, fluvioglacial, fluvial and lacustrine deposits, mainly of Late Pleistocene-Holocene age (fig. 3b; Giraudi, 1994).

In the central-western part of the Gran Sasso Range, the Campo Imperatore Fault is made of two parallel splays (fig. 3a). The southernmost one has been responsible for the displacement of Late Pleistocene-Holocene cemented slope deposits and colluvial units (Carraro and Giardino, 1992), while the northernmost splay affects the slope and the main E-W divide of the chain, displacing the glacial cirque of Mt. Brancastello. This cirque fed a glacial tongue related to the LGM and its displacement is, therefore, subsequent to 22600 years BP (age of the LGM in the Central Apennines, i.e. the Campo Imperatore Stade by Giraudi and Frezzotti, 1997).

The western portion of the fault affects the Maone and Venacquaro valleys, located at more than $1900 \mathrm{~m}$ a.s.l. (fig. 3a). In this part of the Gran Sasso Range, the fault displaced glacial till, colluvial, alluvial and palustrine deposits of Late Pleistocene-Holocene age (Giraudi and Frezzotti, 1995). Impressive fault scarps can be detected in these deposits. Paleoseismological investigations defined four displacement events in the last 18000 years (Giraudi and Frezzotti, 1995). The most recent event occurred after $3490 \pm 160$ years BP. The fault is sealed by a number of colluvial units whose presence corroborates the conclusion by Giraudi and Frezzotti (1995) that the fault activity occurred before 1000 A.D. The recurrence interval defined through these paleoseismological analyses ranges between 2500-3000 and 60007000 years. The authors also defined a vertical slip rate of $0.67-1 \mathrm{~mm} / \mathrm{yr}$.

\section{Geomorphologic framework of the trench area}

The Mt. Paradiso alluvial fan (area of the paleoseismological investigation) is located in the central portion of the Campo Imperatore Plain. The fan was built during six alluvial phases (fig. 3b). Deposition can be chronologically constrained through the comparison with the adjacent Fornaca alluvial fan (showing the same alluvial phases and radiocarbon dated by Giraudi and Frezzotti, 1997) and the case history on the Late Pleistocene-Holocene alluvial deposition of the Abruzzi Apennines (Frezzotti and Giraudi, 1992; Giraudi, 1994; Giraudi and Frezzotti 1997). According to Giraudi and Frezzotti (1997) the first building phase of the Fornaca fan occurred before the formation of a paleosol dated at $31500 \pm 550$ years BP, while the second phase occurred in the period close to the LGM, since the related deposits are sealed by a paleosol dated at $17840 \pm 200$ years BP. Based on the chronological constraints available for another large alluvial fan of the Central Apennines (Majelama alluvial fan; Frezzotti and Giraudi, 1992), showing the same number of depositional phases defined for the Mt. Paradiso fan, the 5th and the 6th phases of fan building may be related to the boundary Late Pleistocene-Holocene (about 12000 years BP) and to 3800-3200 years BP. Therefore, the 3rd and 4th alluvial phases occurred between the LGM and the beginning of the Holocene and can be related to the resistatic episodes of the Late Glacial period.

An evident bedrock fault scarp affects Mt. Paradiso (figs. 3b and 4a). Its western prolongation is defined by a scarp in the unconsolidated gravels of the Mt. Paradiso fan, in the part deposited during the 2nd phase (fig. 3b; between $31500 \pm 550$ years BP and $17840 \pm$ \pm 200 years BP). The entire fault branch is about $1.6 \mathrm{~km}$ long and being located $2 \mathrm{~km}$ south of the main fault bordering the Gran Sasso Chain, it probably represents a secondary normal fault dipping southwards. South of this fault, several scarps (shorter than $1 \mathrm{~km}$, about $1 \mathrm{~m}$ high) can be detected on the Mt. Paradiso fan (fig. 3b), bounding small graben-like features on the top of the fan in the sectors built during the 1 st (before $31500 \pm 550$ years BP) and 2 nd phases.

The paleoseismological analysis was performed by means of trenches excavated across these scarps. 

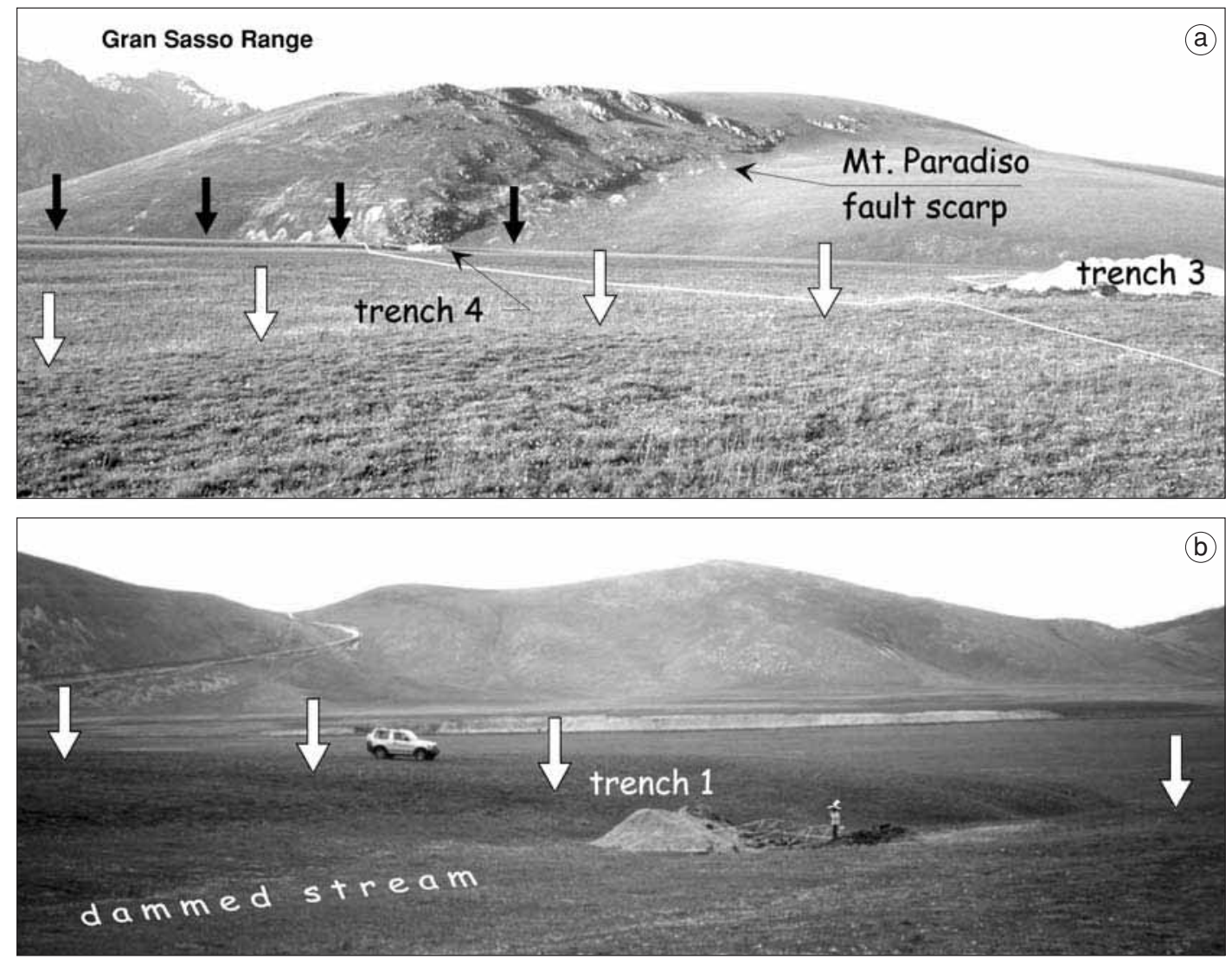

Fig. 4a,b. a) View looking NE of the area of trenches 3 and 4; the black arrows mark the northernmost scarp (facing south) while the white arrows mark the north facing scarp across which trench 3 has been excavated. b) View looking SE of the scarp (white arrows) across which the trenches 1 and 2 have been excavated.

\section{Paleoseismological analysis}

The main purpose of our work was to confirm the previous hypotheses on the Late Pleistocene-Holocene activity of the Campo Imperatore area and to define the chronology of single displacement events.

The main fault affecting the Campo Imperatore area is located along a carbonate slope (fig. 2). Investigations along this fault cannot give significant chronological data with traditional approaches. For this reason, the analyses have been made through trenches excavated across the secondary faults described in the previous section.
The identification of the trench sites has followed the traditional geomorphological criteria. The investigated short faults affect the top surface of the Late Pleistocene-Holocene Mt. Paradiso alluvial fan and are easily detectable through aerial photographs and field surveys, since they have been responsible for the formation of scarps in unconsolidated deposits. Some of the scarps are related to the activity of fault planes with a dip direction opposite to the drainage on the alluvial fan. Therefore, the fault activity was responsible for damming minor streams and inducing deposition (of fine sediments too) in front of the 
scarps (fig. 4b). This is a general condition for the availability of datable material and for this reason three trenches (nos. 1, 2 and 3) were excavated across two N-sloping scarps, forming small sedimentary traps. Trench 4 was excavated across a scarp formed by a fault plane dipping towards south (figs. $3 \mathrm{~b}$ and $4 \mathrm{a}$ ). We made this trench to define the displacement history preceding $31500 \pm 550$ years BP. Although the fault responsible for the formation of the scarp was clearly visible in the trench (fig. 5), no significant stratigraphic markers were found. The trench walls, indeed, only showed the gravels of the 1st phase alluvial fan and gave no evidence for correlating units of gravels across the fault. For this reason, this trench will not be described in detail in the next sections.
Close to trench 1, qualitative geomorphic correlation of the flanks of a stream across the scarp suggests that a dextral component (about $10 \mathrm{~m}$ ) can be attributed to the fault. This component, however, cannot be precisely quantified due to the strong irregularity of the stream flanks. The horizontal displacement in the order of several metres is consistent with the relatively old age of stream formation, subsequent to $31500 \pm 550$ years $\mathrm{BP}$ (age of the alluvial fan) but older than the colluvial deposits filling the incisions, uncovered in trench 2 (see below) and related to the upper Late Pleistocene.

Trench walls were analysed through the definition of stratigraphic units and their relationship with the shear planes and by reporting

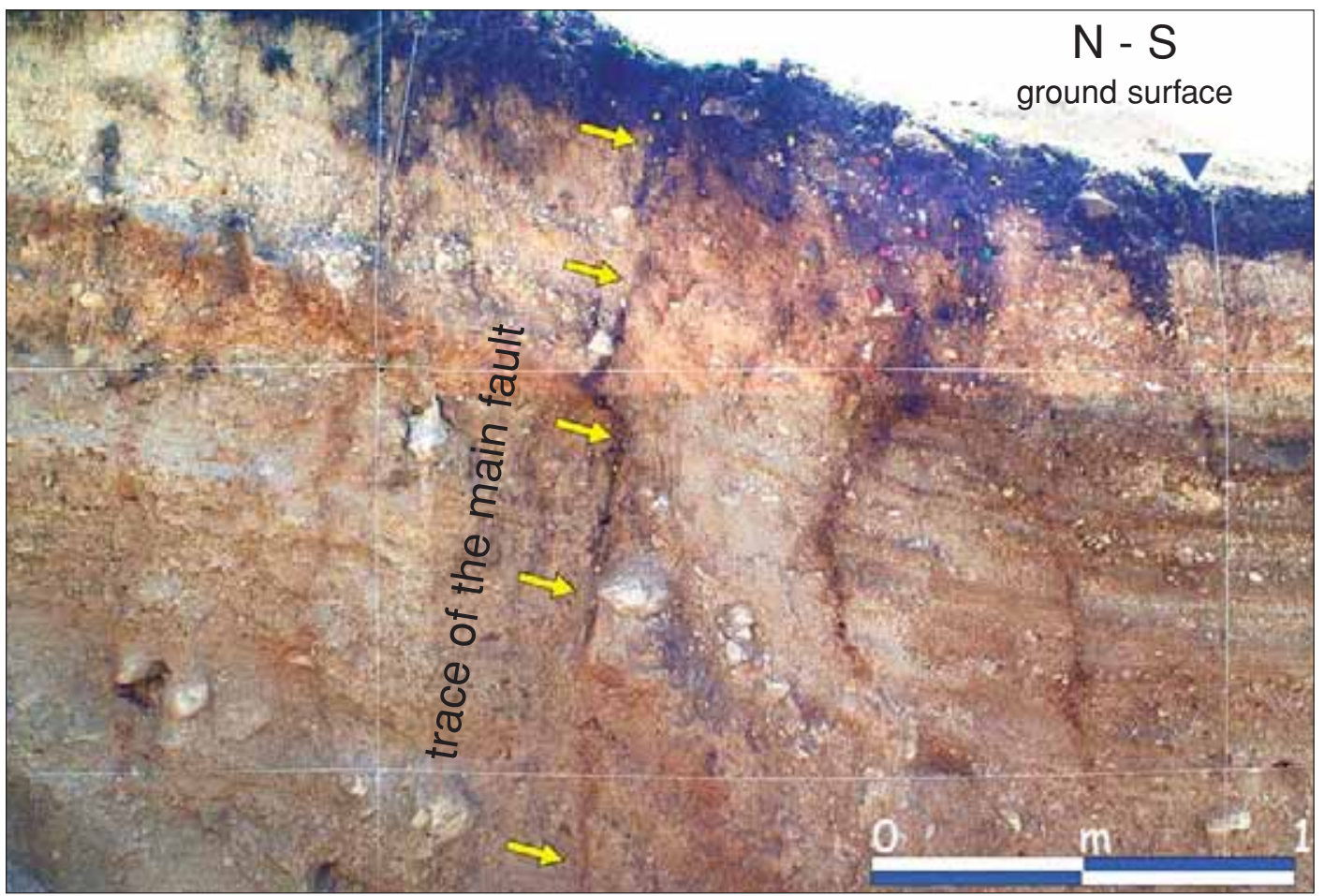

Fig. 5. Photomosaic of the eastern wall of trench 4, excavated across the northernmost fault of the Mt. Paradiso fan (Campo Imperatore Fault). The trench was dug in the gravels of the 1st alluvial fan phase (preceding $31500 \pm$ \pm 550 years BP); units across the fault zone cannot be correlated and only a generic activity since the Late Pleistocene can be defined; arrows mark the main shear plane affecting the gravels. 
Table I. Radiocarbon dates of samples collected in the trenches excavated in the Campo Imperatore area. $\mathrm{R}$ - radiometric technique; BLC - bulk/low carbon material procedure.

\begin{tabular}{|c|c|c|c|c|c|c|c|c|}
\hline Sample & $\begin{array}{l}\text { Lab. code } \\
\text { Beta }\end{array}$ & Analysis & $\begin{array}{l}\mathrm{C}^{13} / \mathrm{C}^{12} \\
\text { ratio }\end{array}$ & $\begin{array}{l}\text { Measured } \\
\text { age BP }\end{array}$ & $\begin{array}{l}\text { Conventional } \\
\text { age BP }\end{array}$ & $\begin{array}{l}\text { Calibrated age } \\
\quad 1 \sigma \mathrm{BP}\end{array}$ & $\begin{array}{l}\text { Calibrated age } \\
\quad 2 \sigma \mathrm{BP}\end{array}$ & $\begin{array}{c}\text { Sample } \\
\text { description }\end{array}$ \\
\hline CIMP1 & 139363 & $\mathrm{R}, \mathrm{BLC}$ & $-23.1 \%$ & $6790 \pm 60$ & $6820 \pm 60$ & $7690-7605$ & $7750-7580$ & $\begin{array}{l}\text { Buried soil } \\
\text { (silty sand) }\end{array}$ \\
\hline CIMP3 & 139364 & $\mathrm{R}$ & $-24.1 \%$ & $4470 \pm 40$ & $4480 \pm 40$ & $5285-5155 / 5145-5040$ & $5300-4970$ & $\begin{array}{l}\text { Buried soil } \\
\text { (silty sand) }\end{array}$ \\
\hline CIMP4 & 139365 & $\mathrm{R}$ & $-24.1 \%$ & $4760 \pm 40$ & $4780 \pm 40$ & $5590-5565 / 5545-5475$ & $5600-5460 / 5370-5340$ & $\begin{array}{l}\text { Buried soil } \\
\text { (silty sand) }\end{array}$ \\
\hline CIMP5 & 139366 & $\mathrm{R}$ & $-23.9 \%$ & $3530 \pm 40$ & $3540 \pm 40$ & $3870-3815 / 3785-3730$ & $3915-3700$ & $\begin{array}{l}\text { Buried soil } \\
\text { (silty sand) }\end{array}$ \\
\hline CIMP6 & 139367 & $\mathrm{R}$ & $-24.3 \%$ & $3790 \pm 40$ & $3800 \pm 40$ & $4245-4140 / 4115-4100$ & $4290-4080$ & $\begin{array}{l}\text { Buried soil } \\
\text { (silty sand) }\end{array}$ \\
\hline CIMP7 & 139368 & $\mathrm{R}$ & $-24.1 \%$ & $3230 \pm 40$ & $3240 \pm 40$ & $3480-3400$ & $3560-3375$ & $\begin{array}{l}\text { Buried soil } \\
\text { (silty sand) }\end{array}$ \\
\hline CIMP8 & 139369 & $\mathrm{R}$ & $-24.1 \%$ & $3970 \pm 40$ & $3980 \pm 40$ & $4510-4475 / 4445-4410$ & $4530-4380$ & $\begin{array}{l}\text { Buried soil } \\
\text { (silty sand) }\end{array}$ \\
\hline CIMP9 & 139370 & $\mathrm{R}, \mathrm{BLC}$ & $-22.6 \%$ & $6050 \pm 100$ & $6090 \pm 100$ & 7155-7120/7035-6790 & $7240-6690$ & $\begin{array}{l}\text { Colluvium } \\
\text { (silt) }\end{array}$ \\
\hline CIMP11 & 1139371 & $\mathrm{R}$ & $-23.6 \%$ & $2340 \pm 70$ & $2370 \pm 70$ & $2465-2335$ & $2720-2310 / 2230-2190$ & $\begin{array}{l}\text { Colluviated soil } \\
\text { (silt) }\end{array}$ \\
\hline CIMP12 & 2139372 & $\mathrm{R}$ & $-23.9 \%$ & $2250 \pm 40$ & $2270 \pm 40$ & $2340-2310 / 2230-2190$ & $2350-2290 / 2270-2155$ & $\begin{array}{l}\text { Colluviated soil } \\
\text { (silt) }\end{array}$ \\
\hline
\end{tabular}

the information on graph paper. Samples were collected for radiocarbon dating (table I) from a paleosol (CIMP-1, -3, -4, -5, -6, -7, -8) or from colluviated material (CIMP-9, -11, -12), which gives a minimum age for the deposition. The samples were analysed by Beta Analytic Inc. (Miami, Florida) and calibrated by means of the INTCAL98 database (Stuiver et al., 1998). In the following sections, we report the $1 \sigma$ calibrated results ( $68 \%$ of probability). However, table I also gives the $2 \sigma$ results, thus giving the possibility to define the related chronological constraints.

Chronological constraints were also derived from the Late Pleistocene-Holocene stratigraphic framework of the Abruzzi Apennines, defined by a number of works dealing with paleoclimatic issues (e.g., Frezzotti and Giraudi, 1989, 1990; Frezzotti and Narcisi, 1989, 1996, Giraudi, 1994, 1998a,b; Giraudi and Frezzotti, 1997). These authors have defined chronologically constrained (numerical and archaeological datings) depositional events (alluvial, colluvial, lacustrine, aeolic, ...) and pedogenetic phases in the investigated region since about 30000 years BP.

\subsection{Trench 1}

Units 2 and 3 of fig. $6 a$, b represent the A and B-C horizons of an andisol, respectively. Andisols in the Central Apennines (characterised by the typical blackish colour) formed from colluviated «Neapolitan Yellow Tuff» (see Frezzotti and Narcisi, 1996, on this point). Remnants of the parent material are evident within unit 3 . The eruption (related to the volcanic activity of the Phlegrean Fields, close to Neaples) was dated to about 14120 years BP (date used in the sections dedicated to the paleoseismological analysis) on the basis of the varvesupported sedimentation rate (Zolitschka and Negendank, 1996) and at about 14200 years BP on the basis of ${ }^{14} \mathrm{C}$ chronological constraints (Asioli et al., 2001; Siani et al., 2001). Six radiocarbon dates are available for unit 2 (table I) and one for unit 3 (7690-7605 years BP, $1 \sigma$ cal age). Considering the climate history following the deposition of the «Neapolitan Yellow Tuff», its pedogenesis probably began at the end of the Younger Dryas (at the boundary Late Pleistocene-Holocene), i.e. after a long 


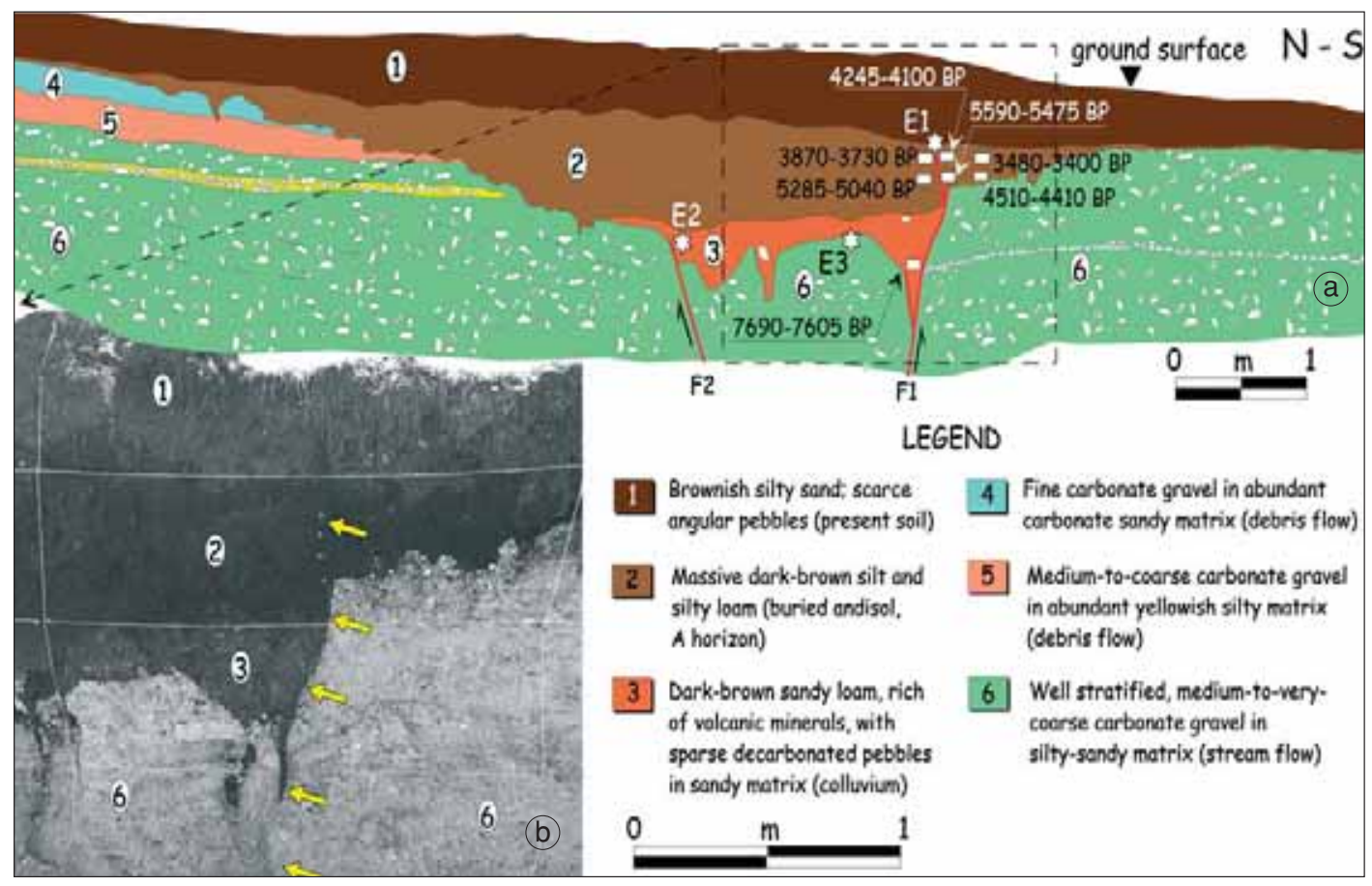

Fig. 6a,b. a) Log of the $\mathrm{E}$ wall of trench 1 excavated across one of the faults affecting the Mt. Paradiso alluvial fan, Campo Imperatore Fault (see fig. 3b for location); at least two events occurred after about 14000 years BP (see text for explanation) can be detected through the paleoseismological analysis. b) View of the E trench wall in the sector affected by the fault F1.

period of aridity not favourable to the action of the pedogenetic processes. Units 4, 5 and 6 are made of gravels whose deposition can be related to debris flows $(4,5$ in fig. $6 a)$ or stream flows ( 6 in fig. $6 a, b)$. Two fault planes bounding a small graben can be detected in the eastern trench wall (F1 and F2 in fig. 6a). Fault F1 was responsible for the displacement of units 6 , 3 and 2, while F2 displaced units 6 and 3, being apparently sealed by unit 2 (fig. 6a).

Two displacement events were defined through the analysis of this trench.

The youngest event (E1) was responsible for the displacement of the A horizon of the andisol (unit 2) across the fault F1. Considering that the paleosol is buried and no evidence of contamination from the present soil (e.g., root penetration) was observed, the youngest age of the andisol (3480-3400 years BP) represents a reliable lower chronological limit for E1. In contrast, an upper chronological limit cannot be defined, since F1 is sealed by the present soil whose origin (parent material) is unknown. For this reason, we did not date samples from unit 1 and preferred to maintain the problem of the upper chronological limit of E1 unsolved.

No estimate of the vertical offset can be provided, due to the irregular attitude of the unit 2 base and to the evidence of horizontal movements (see previous section). The latter may create apparent vertical movements in horizontally displaced irregular surfaces.

An older event (E2) is indicated by the presence of thick unit 3 deposits between F1 and F2 (fig. 6a,b). This may suggest that the deposition of unit 3 occurred within the depression created 
by the movement along the two faults and that the displacement event occurred slightly before the deposition of unit 3. The event may also be suggested by the erosional surface carved into the gravels of unit 6 in the footwall (south of F1), possibly related to the retreat of a paleoscarp before the unit 3 deposition. If we accept that the deposition of unit 3 occurred within the depression created by the fault movement during E2, this event has approximately the same age of the «Yellow Neapolitan Tuff», i.e. about 14120 years BP. Alternatively, we may hypothesise that faulting occurred after the deposition of the tephra. The thickness of unit 3 increased in the lowered part due to colluviation from the uplifted footwall. This conditioned the pedogenesis, as a larger thickness of andisol formed in the lowered part of the fault (where also the B$\mathrm{C}$ horizon, i.e. remnants of the original tephra, are preserved). In such a case, E2 occurred after the deposition of the "Yellow Neapolitan Tuff», i.e. after $c a$. 14120 years BP. The upper chronological limit for E2 would be represented by the oldest chronology of the A horizon (not affected by the same offset of the B-C horizon). E2 would have occurred, therefore, between 14120 years BP and 5590-5565/5545-5475 years BP. We prefer this second hypothesis on the basis of the comparison with the succession of events defined in trench 2 (see next section) showing the occurrence of an E2 event after 71557120/7035-6790 years BP. It is probable, therefore, that the event E2 of trench 1 occurred after the date (7690-7605 years BP) reported in the $\log$ of fig. $6 \mathrm{a}, \mathrm{b}$, related to a phase of the pedogenetic history of the colluviated «Yellow Neapolitan Tuff».

The E2 event is also testified: 1) by the upper termination of fault F2, which does not cut the boundary between units 2 and 3, and 2 ) by the fact that in the sector close to F1, unit 3 fills a triangular area in fig. 6a, probably related to an open fissure which did not affect unit 2.

The lack of unit 3 in the footwall (although it was present there, since the andisol formed also south of F1) and the irregular shape of the unit 3 base make the estimation of the vertical offset difficult. A rough evaluation of the minimum offset (related to E1 + E2) may be ob- tained by calculating the vertical separation between the most regular part of the unit 3 base and the base of unit 2 in the footwall of F1 (far from possible effects of paleoscarp retreat, fig. 6a. This estimate gives $0.63 \mathrm{~m}$.

If we accept the second hypothesis about the E2 event, the erosional surface carved into the gravels of unit 6 in the footwall (suggesting paleoscarp retreat processes) may suggest an event E3, which occurred slightly before the deposition of the «Yellow Neapolitan Tuff», i.e. slightly before 14120 years BP. This evidence is, however, too faint to ascertain the occurrence of an E3 event.

\subsection{Trench 2}

The excavation uncovered a number of stratigraphic units made of carbonate gravels related to debris flow $(2,4,6,11,12$ in fig. $7 \mathrm{a}, \mathrm{b})$ and stream flow $(8,9,10$ in fig. $7 \mathrm{a}, \mathrm{b})$ episodes. The present soil (unit 1) is black and pulverulent. These two characteristics suggest that current pedogenesis is acting over a colluviated andisol. Colluviation (also indicated by the presence of carbonate clasts within unit 1) probably occurred as a result of a crisis of the andisol during an arid Late Holocene period. This period is subsequent to the youngest date available for the andisol of trench 1 (3480-3400 years BP). Available works with a paleoclimatic perspective (e.g., Giraudi, 1995, 1997), define an arid period that began close to the above reported date and lasted until 2800-2700 years BP. Deposition of the parent material of unit 1 probably occurred during this time interval.

A colluvial origin can be hypothesized for the massive sandy silt with sparse pebbles of unit 3 (colluviation of a soil) and for the gravel of unit 7. A radiocarbon date is available for unit 3 (7155-7120/7035-6790 years BP), which defines a lower chronological limit for the deposition. Unit 7 displays a faint stratification indicating a deposition over a gentle slope dipping northwards. The matrix is scarce and the deposit is prevalently clast supported. Moreover it outcrops only in the area affected by the faults. In short, sedimentological fea- 


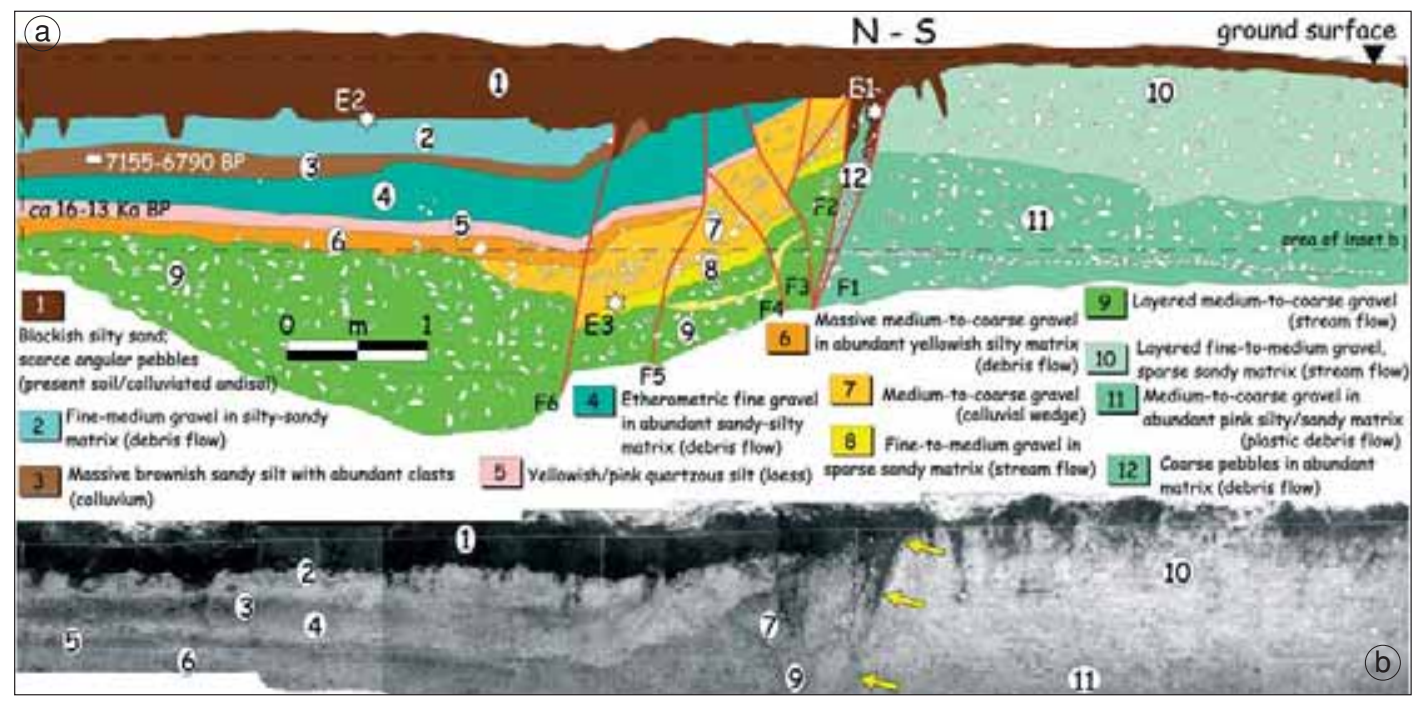

Fig. 7a,b. a) Log of the E wall of trench 2 excavated across one of the faults affecting the Mt. Paradiso alluvial fan, Campo Imperatore Fault (see fig. 3b for location); three events occurred after $31500 \pm 550$ years BP can be detected through the paleoseismological analysis. b) View of the E trench wall; the arrows mark the fault F1.

tures and the geometry of unit 7 indicate that it represents the product of scarp retreat following a displacement event along the fault zone.

Unit 5 is a quartzic loess; similar deposits have been found in other areas of the Central Apennines (Frezzotti and Giraudi, 1989, 1990) and related to aeolic deposition fed by the Saharian region. Frezzotti and Giraudi (1989, 1990) attributed a specific paleoclimatic significance to the aeolic deposition. In particular, the loess deposition in the Aremogna Plain (about $70 \mathrm{~km}$ south of Campo Imperatore) has been related to a period between $16000-15000$ years BP (age of the Buhl-Schlern stades in the Alps, corresponding to arid and cold climatic periods) and $12850 \pm 200$ years BP (radiocarbon age of a peat level subsequent to the loess deposition). The same chronological constraint has been defined for the quartzic aeolic deposit found in other areas close to the Aremogna Plain, i.e. Mt. Greco and Matese Mts. (Frezzotti and Giraudi, 1990). On this basis, we hypothesize that unit 5 was deposited between 15000-16000 years BP and $12850 \pm 200$ years BP.
Further chronological constraints are available for units 10 to 12 which are part of the alluvial fan succession related to the Late Pleistocene, older than $31500 \pm 550$ years BP (see section dedicated to the active tectonic framework).

The eastern trench wall is affected by six fault planes. The shear planes F1 and F2 (fig. 7a) have been interpreted as the main fault zone, since they place in contact units of gravels which cannot be correlated across the investigated trench wall. This means that this fault zone is characterised by an offset larger than that affecting the units of the northern part of the trench, along the F3-F6 fault planes (fig. 7a). Faults F3-F5 have been responsible for the displacement of units 4 to 9 , while the fault F6 has also been responsible for the displacement of unit 3 and perhaps of unit 1 (present soil).

Although a lowering of the displaced units northwards is visible (suggesting that the displacements are characterised by a normal component), the different vertical offset (e.g., higher in unit 5 than in unit 8 ) along F5 and the 
different sense of displacement observed along some surfaces (e.g., compare the offset of the unit 7 base with that of the base and top of unit 5 ; compare the offset of the unit 4 base with that affecting the top of the same unit) suggest that the units have also been horizontally displaced. However, the amount of horizontal offset cannot be estimated. Three displacement events were detected through an analysis of the section reported in fig. 7a. The youngest faulting (E1) was responsible for the displacement of the base of the present soil, across the fault zone F1-F2. An open fissure formed between $\mathrm{F} 1$ and F2, which was filled by the material of unit 1. The displacement of the base of unit 1 may also have occurred along the fault F6. The vertical displacement (estimation of the vertical separation of the base of unit 1 across the fault zone) is $0.38 \mathrm{~m}$. Since unit 1 is forming over the colluvium derived from the andisol, its displacement occurred after the colluvial deposition. Based on the characteristics of unit 1 defined at the beginning of this section, this deposition occurred between 3480-3400 years $\mathrm{BP}$ (youngest available age for the andisol) and 2800-2700 years BP. E1 occurred, therefore, after 3480-3400 years BP.

A previous event (E2) is indicated by the tilting of units 3 to 6 between the faults F6 and F2. As a result of this deformation, subsequent to the deposition of unit 7 (see E3 event below), the stratification and the boundary of deposits with northern provenance (streams as well as the top of the alluvial fan dip southwards), are dipping northwards. As for the chronology of the displacement, E2 occurred after $7155-7120 / 7035-6790$ years BP $(1 \sigma)$, age derived from a sample of unit 3 . The deformation is sealed by unit 1 (present soil), as suggested by the evident unconformity between this unit and the older ones. The southernmost outcropping part of unit 2, indeed, seems to be involved in the warping of the older units. The deposition of the parent material of unit 1 occurred between 3480-3400 years BP $(1 \sigma)$ and 2800-2700 years BP and therefore the reported dates represent the upper chronological limit of E2.

The lack of deposits which can be correlated across the entire investigated section prevents the possibility of defining the vertical displacement (fig. 7a). An estimation of the minimum vertical offset (comprising, however, the offset along F6, which may also record E1) can be obtained from the vertical separation of the furthest available points of the unit 5 base, which is one of the most regular surfaces available in the investigated section. This minimum offset is $0.80 \mathrm{~m}$.

A previous event (E3) is testified by unit 7, made of deposits which have been fed from the south, i.e. from a scarp formed in the area affected by the faults. Unit 7 was interpreted as a colluvial wedge derived from the retreat of a scarp due to a displacement along F1-F2. The chronology of E3 is constrained by the age of units 9 and 5. The former is part of the alluvial succession which makes the Mt. Paradiso fan. Since unit 9 is close to the top of the 1st phase alluvial fan and the deposits are preserved in the fault hangingwall (i.e. they are part of the youngest gravel unit of the 1st phase uncovered in the trench), it is probable that its deposition occurred close to $31500 \pm$ \pm 550 years BP (age of the soil formed after this alluvial phase, according to Giraudi and Frezzotti, 1997). Unit 5 was instead chronologically constrained (between 16000-15000 years BP and $12850 \pm 200$ years BP) through the works by Frezzotti and Giraudi (1989, 1990). This means that more than 15000 years passed between the deposition of units 9 and 5. The lack of deposition or very limited deposition during this long time interval is probably due to the end of operation of the old Mt. Paradiso fan system, and to the deposition of a younger alluvial fan (located elsewhere) with the post-LGM fluvioglacial phases (fig. $3 b)$. The trench area experienced, in the same period, water flow within the incisions carved into the pre- $31500 \pm 550$ years BP fan. Considering this kind of evolution, the new depositional activity (from unit 6 to unit 2) has probably been conditioned by the presence of a scarp damming an area affected by small streams (fig. 4b) and therefore creating the conditions for sedimentary traps. The presence of a scarp derived from the fault displacement and the subsequent deposition of unit 7 during the scarp retreat is also proved 
by the thinning of unit 5 towards south and by the end, with a lenticular geometry, of unit 6 towards the same direction (fig. 7a). Since unit 7 is overlaid by unit 5 (south of F5), whose chronology is $16000-15000$ years BP/12850 \pm \pm 200 years BP, and deposited after unit 9 , whose age is probably slightly older than $31500 \pm 550$ years BP, we consider these chronological constraints as the E3 upper and lower chronological limits, respectively.

Due to the lack of correlative deposits across the fault zone, it is not possible to define the vertical displacement related to this event.

\subsection{Trench 3}

Trench 3 was up-to-2.7-m deep and was excavated across a scarp located north of that of trenches 1 and 2 (see fig. $3 b$ for location). Like the previously described cases, however, the scarp is sloping northwards. It is, therefore, related to a fault plane responsible for the lowering of the northern block.

Stratigraphic units are entirely made of gravels related to various alluvial facies $(4,5,7,8,9$ and 10 in fig. 8a,b) or to colluvial episodes fed from areas adjacent to that of deposition $(2,3,6$ in fig. 8a,b). Unit 1 is the present soil forming over a colluviated older andisol; similarly to unit 1 of trench 2, colluviation of the parent material occurred between $3480-3400$ years BP ( $1 \sigma$ cal age, youngest available radiocarbon date for the andisol) and 2800-2700 years BP. The present pedogenetic phase on the colluviated andisol began, therefore, after the reported ages.

As for unit 3 , it is characterised by pebbles strongly oriented parallel to the unit base. Moreover, these deposits only outcrop in the sector affected by the faults. The geometry and the attitude of the pebbles suggest a local origin, related to a slope dipping northwards. All these aspects indicate that unit 3 represents a colluvial wedge due to the retreat of an N-dipping scarp formed during an episode of faulting.

The eastern trench wall is affected by seven fault planes (F1 to F7 in fig. 8a) which were responsible for the displacement of the entire stratigraphic succession previously described. F1, F2 and F3 affect the gravels (units 6, 9 and 10) of the southern part of the trench and are sealed by unit 1, i.e. the present soil (F1), and by unit 3 (F2 and F3). Unit 3 is, however, affected by fractures without vertical displacement along the upward prolongation of F2 and F3. The central sector of the trench is affected by the fault planes F4 and F5, to which the most recent activity can be related (displacement of units 3 and 1, fissure filled by unit 2).

The fault planes display a high dip $\left(70-80^{\circ}\right)$. Vertical components of the movement are evident along faults F1 to F3 and F6-F7. The different thickness of unit 6 across F3, the high dip of the fault planes, the whole geometry of the displacement (resembling a flower structure) suggest the probable occurrence of horizontal movements (fig. 8a). The amount of horizontal offset, however, cannot be estimated.

Three displacement events were detected through the analysis of the eastern trench wall.

The youngest event (E1), is evident along the fault planes F4 and F5 and is indicated by the small offset $(0.3 \mathrm{~m})$ affecting the present soil (unit 1). The base of unit 1 is lowered in the sector between the two mentioned faults (fig. 8a). Displacements of the unit 1 base were also detected along F7 and F6. As for F7, a horizontal component of the movement may be defined, since the base of unit 1 is lowered north of the fault plane, while units 4 to 8 are uplifted in the same sector (fig. 8a). The horizontal movements affecting units characterized by an irregular geometry and different attitude prevent the possibility of defining the amount of vertical offset.

The lowering of the central part of the trench is also suggested by the larger thickness of the present soil in the faulted sector, probably due to post-faulting colluviation from the southern and northern part of the trench. Considering that unit 1 may represent the pedogenesis of a parent material made of the andisol discovered in trench 1 , and that the colluviation of the andisol occurred between 3480-3400 years BP and 28002700 years BP, faulting related to E1 is subsequent to a moment within the defined time span.

A previous event (E2) is suggested by the formation of the open fissure between F4 and F5, filled by gravels without a sandy or silty fraction derived from the present soil or from the andisol. This aspect indicates that the displacement oc- 


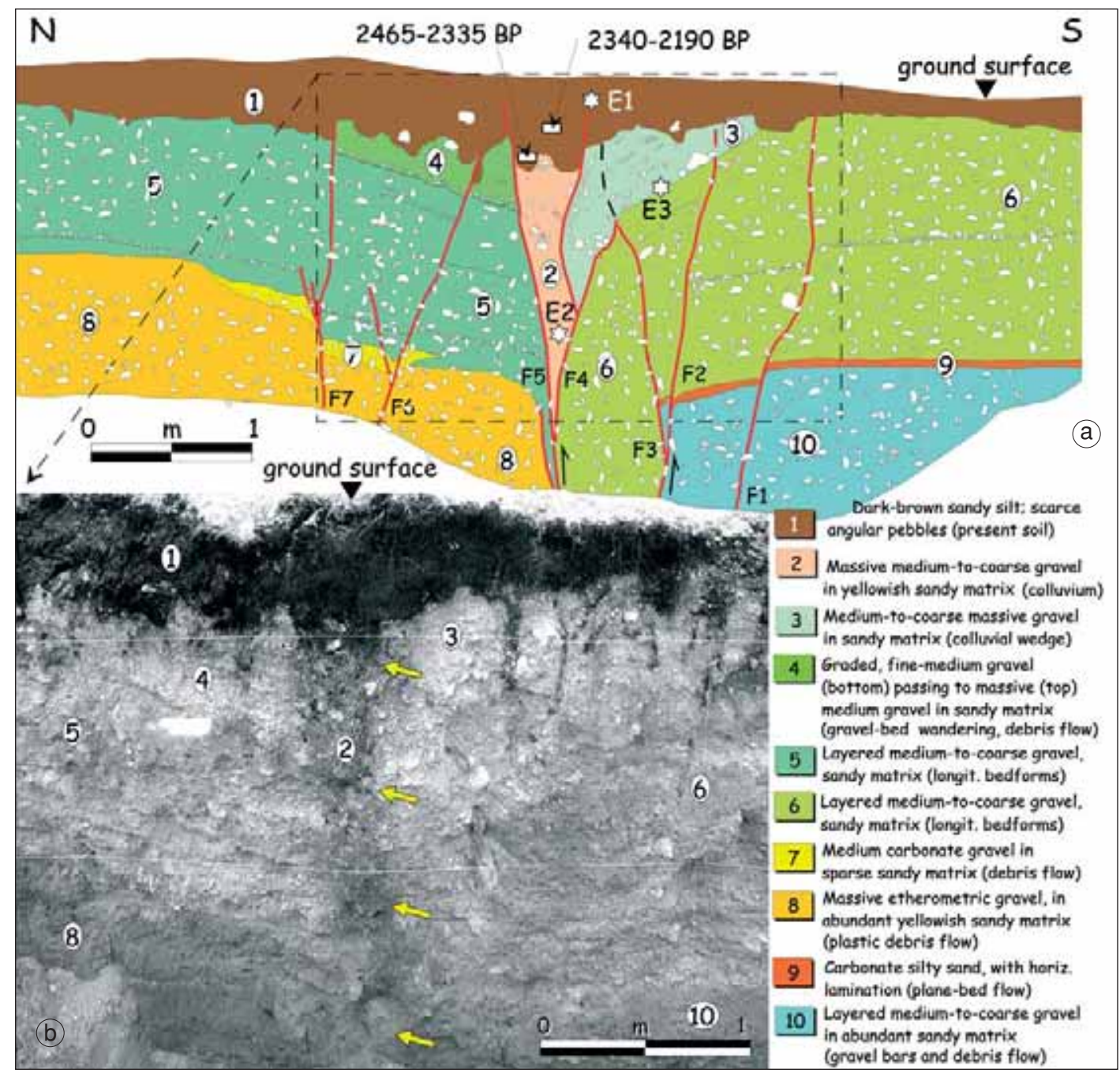

Fig. 8a,b. a) Log of the $\mathrm{E}$ wall of trench 3 excavated across one of the faults affecting the Mt. Paradiso alluvial fan, Campo Imperatore Fault (see fig. $3 \mathrm{~b}$ for location); three events occurred after $31500 \pm 550$ years BP can be detected through the paleoseismological analysis. b) View of the E trench wall in the area affected by the faults; the arrows mark the fault plane F4.

curred before 3480-3400 years BP/2800-2700 years BP. The lower chronological limit is less defined, since no direct dating is available for the displaced gravels. As reported in the previous sections, the gravels are related to an alluvial fan whose top soil has been dated at $31500 \pm 550$ years BP (Giraudi and Frezzotti, 1997). The aerial photographs show that the investigated alluvial fan is everywhere characterized by its original form, representing the depositional top of the alluvial succession. This means that significant erosional episodes did not occur in the investigat- 
ed area after the gravel deposition. The implication of this observation is that the age of the displaced gravels (close to the top of the fan) is probably slightly older than $31500 \pm 550$ years BP. The lower chronological limit for E2 is, therefore, an age preceding (but close to) $31500 \pm$ \pm 550 years BP.

Available data do not permit hypotheses about the correlation between the stratigraphic units exposed in the southern and northern sectors. It is not possible, therefore, to define the vertical offset related to this event.

A previous event (E3) was responsible for the formation of the scarp whose retreat fed the deposition of the colluvial wedge defined as unit 3 in fig. 8a. This colluvial wedge was subsequently faulted, during E2, along fault F4. Also in this case, due to the lack of correlation between the units in the southern part and those in the northern part, there is no possibility to define the vertical offset. The thickness of unit 3 defines, however, a significant amount of material derived from a pre-existing scarp. This suggests a vertical offset larger than that related to E1 (indicated by the small displacement of the unit 1 base). As for the chronology of E3, constraints are the same as E2, i.e. the event occurred after an age slightly preceding $31500 \pm 550$ years BP and before 3480 3400/2800-2700 years BP.

\section{Summary of the displacement events}

The investigated area gave evidence for the occurrence of at least three coseismic displacement events (fig. 9). Two of these events occurred during the Holocene (i.e. E1 and $\mathrm{E} 2$ of trenches 1 and 2), while there is evidence for the occurrence of at least one event during the Late Pleistocene (E3 of trench 2).

Available data (fig. 9) indicate that all the trenches gave evidence for the youngest displacement (E1) after 3480-3400 years BP/2800-2700 years BP. The upper chronological limit for the E1 occurrence is, however, paleoseismologically undefined.

The penultimate seismic event (E2) is constrained at trench 1 , between 14120 years BP and 5590-5565/5545-5475 years BP. This large time span may be reduced if E2 of trench 1 is the same as E2 of trench 2. In such a case, the lower chronological limit is 7155-7120/70356790 years BP. E2 of trench 3 is definitely poorly constrained (between $31500 \pm 550$ years BP and 3480-3400 years BP). It is not possible, therefore, to compare this event to the E2 events found in the other trenches.

Evidence of a Late Pleistocene seismic event is not conclusive in trench 1 (E3), where a retreating scarp may have been buried by the "Yellow

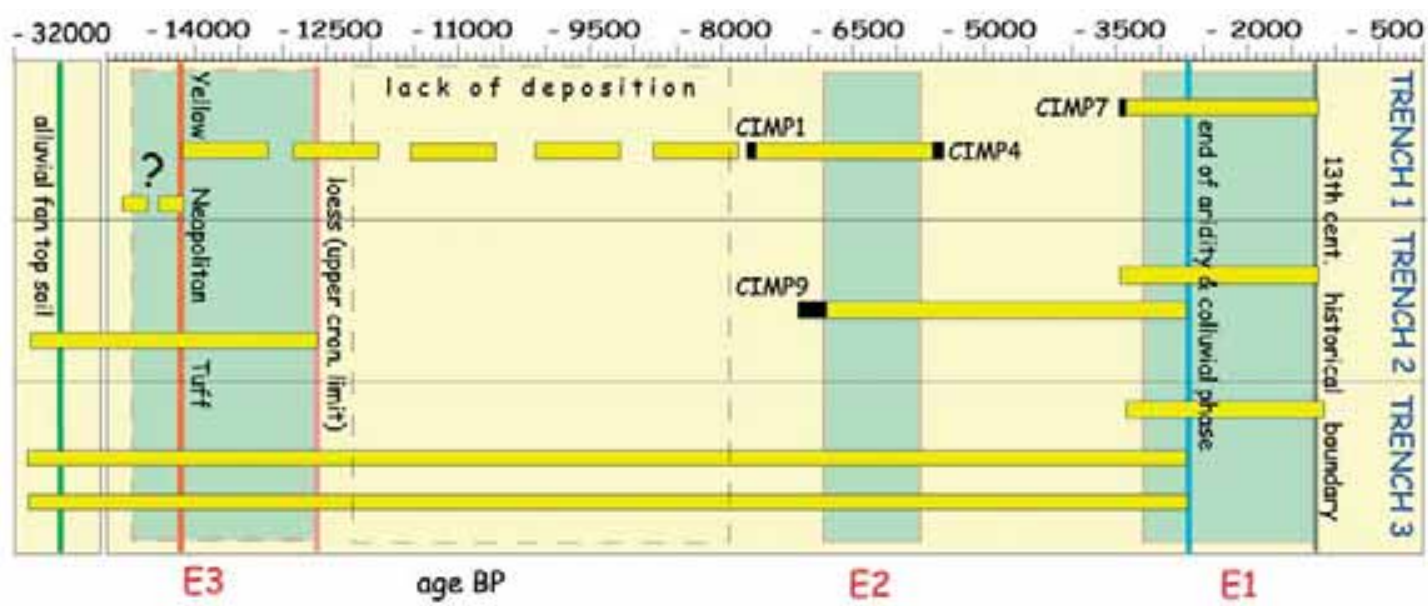

Fig. 9. Chronological constraints for the displacement events paleoseismologically inferred along the faults of the Mt. Paradiso alluvial fan. 
Neapolitan Tuff». This suggests that E3 may have occurred slightly before 14120 years BP. E3 in trench 2 is constrained in a large time span, between $31500 \pm 550$ years BP and $12850 \pm 200$ years BP. The faint evidence for E3 in trench 1 and the chronological uncertainty in trench 2 prevent a comparison of the two events. E3 is also recorded in trench 3 (one of the two events indicated as E2 and E3 in fig. 9). In trench 2, E3 was responsible for the formation of a scarp which fed a quite thick colluvial wedge made of gravel. In trench 3, the same process was caused by E3. Possibly, the E3 events defined in trenches 2 and 3 are related to the same displacement, responsible for the formation of relatively high scarps in unconsolidated gravels.

\section{Fault behaviour}

\subsection{Slip rate}

The paleoseismological trenches in the Campo Imperatore area were excavated across secondary faults. For this reason, data derived from the trenches made across the scarps on the Mt. Paradiso fan (Campo Imperatore Fault) cannot give information on the vertical slip rate of the primary fault. In this case, therefore, we cannot give updated information on the slip rate. The value which will be considered is, therefore, $0.67-1 \mathrm{~mm} / \mathrm{yr}$, produced by Giraudi and Frezzotti (1995).

\subsection{Elapsed time since the last activation}

The paleoseismological analysis did not define precise upper chronological limits for the observed displacements. In the investigated case, the displacement also affects the present soil, due to faulting after 3480-3400 years BP/2800-2700 years BP. The lack of sealing units makes, therefore, the definition of the elapsed time since the last fault activation impossible. An indication about the elapsed time for the Campo Imperatore Fault may be derived from the data published by Giraudi and Frezzotti (1995). The authors reported that the fault is sealed by some colluvial units; the defined stratigraphic setting seems to corroborate the authors' conclusion about the lack of activation in the past 1000 years (based on the absence of historical earthquakes which may be consistent with the activation of the fault). This suggests that the last activation probably occurred in early historical times or in prehistorical times.

The association of historical earthquakes with Central Apennine active faults suggests that no earthquakes of $M>6$ may be related to the activation of the Campo Imperatore faults (e.g., Galadini et al., 1999; Barchi et al., 2000; Galadini and Galli, 2000; Valensise and Pantosti, 2001). Available historical catalogues (Boschi et al., 1995, 1997, 2000; Camassi and Stucchi, 1997; Working Group CPTI, 1999) give reliable information on the occurrence of large magnitude earthquakes since the first centuries of the 2 nd millennium A.D. Recent studies on the completeness of the historical information for the largest magnitude events defined a low probability of lost historical information in the period 1200 A.D.Present (Stucchi and Albini, 2000). On this basis, we define eight centuries as a sort of «conventional» minimum elapsed time for the Campo Imperatore Fault.

\subsection{Recurrence interval}

Radiocarbon dates permit hypotheses to be made on the time span between the defined displacement events. As shown by the stratigraphy of trenches 1 and 2, deposition during the Holocene was conditioned by the presence of a scarp which dammed the course of minor streams. Due to the continuous sedimentary succession, the E1 and E2 seismic events recorded in the trenches 1 and 2 possibly represent consecutive displacements. An evaluation of the time span between E2 and E1 can be obtained by defining an upper chronological limit for E1. It is highly probable that E1 did not occur after 1200 A.D. (see previous section). Therefore, the maximum time span between $\mathrm{E} 2$ and $\mathrm{E} 1$ can be defined from the difference between the oldest age of the E2 occurrence (i.e. the oldest age of unit 3 in trench 2, 7155 years BP) and the upper chronological limit of E1 (i.e. 1200 A.D.). The maximum time span is 6405 years. 
The minimum time span can be obtained from the difference between the upper chronological limit of E2 (i.e. the youngest lower chronological limit of unit 2 in trench 1, 5475 years BP) and the oldest chronological limit of E1 (i.e. the oldest upper chronological limit of unit 2 in trench 1 , 3480 years BP). The minimum time span between E2 and E1 is, therefore, 1995 years. Based on the available ages, the time span between E2 and E1 is 1995-6405 years.

This conclusion is consistent with the available data on the recurrence intervals of other faults in the Abruzzi Apennines (Pantosti et al., 1996; Galadini and Galli, 1999; D'Addezio et al., 2001).

\subsection{Expected magnitude}

We defined the maximun expected magnitude from the surficial fault length, by using the equation linking the Surface Rupture Length (SRL) with the moment magnitude (Wells and Coppersmith, 1994). The SRL of the Campo Imperatore Fault has been mapped in detail through the observation of aerial photographs and subsequent investigations in the field during the last decade. The definition of the length of the fault surficial expression in the Gran Sasso Range is definitely complicated. Indeed, three different segments (Assergi, Campo Imperatore and Mt. San Vito-Mt. Cappucciata) can be defined and no data are available which define the relationship between the three faults during an earthquake. It is probable, however, that the impressive scarp formed along the Mt. Cappucciata-Mt. San Vito Fault (15 km long) and the displacements of the Late Pleistocene deposits (reported in Galadini and Galli, 2000) are due to coseismic events with energy larger than that expected from the activation of such a short segment. Moreover, the Assergi Fault is parallel and very close to the Campo Imperatore Fault for about half of its length (figs. 1 and 3a). This geometry suggests a connection at depth between the two faults. On this basis we believe that the entire $38 \mathrm{~km}$ long structure made of the three fault segments is the surficial expression of a single seismogenic source. The expected magnitude is, therefore, 6.95 (Wells and Coppersmith, 1994).

\section{Damage scenario related to the Gran Sasso Range Fault}

As reported in the previous sections, although the investigated fault ruptured during the Holocene, at present it cannot be related to any historical earthquake. It is interesting, therefore, to analyse the effects of the fault activation through the production of a damage scenario. Thus, we tried to reproduce the intensity distribution generated by the investigated fault related to the maximum magnitude event expected from the activation of the Gran Sasso Range source.

The damage scenario was generated starting from a computer code implemented in the Emergency Management System (SIGE), developed by the Seismic Survey of Italy for civil protection purposes (Di Pasquale et al., 1998). The computer code was recently updated (FaCES, Fault Controlled Earthquake Scenario, in Galli et al., 2002b) to take into account the geometrical characteristics of the source. In short, the input data for FaCES are represented by the following source parameters: L - fault length; AZ - strike of the fault $\left(0^{\circ}-360^{\circ}\right)$; $\mathrm{H}$ - maximum depth of the fault rupture (hypocenter, kilometer); CC - coordinates of the fault medium point at depth (hypocenter); D - ratio of anisotropy of the attenuation law (0-1); $\Psi$ azimuth of the minimum attenuation direction from the fault $\left(0^{\circ}-360^{\circ}\right) ; \mathrm{R}$ - cutback of the $M / I_{0}$ relationship for depth $>10 \mathrm{~km}(0-1)$.

Figure 10a,b shows the parameters used for the investigated fault. We assumed $10 \mathrm{~km}$ as the hypocentral depth of earthquakes potentially triggered by the faults. Moreover, the medium point of the lowest portion of the fault area at depth defined the hypocentral coordinates. The values for $\mathrm{D}, \Psi$ and $\mathrm{R}$ were derived from the comparison between FaCES and the Highest Intensity Datapoint Distribution (HIDD) of historical Italian earthquakes and the geometry of the related seismogenic sources (Galli et al., $2002 \mathrm{~b}$ ). We adopted $\Psi=350^{\circ}$ simulating an along-strike directivity effect towards the $\mathrm{W}$ (nevertheless, $\Psi=190^{\circ}$ may be used to simulate an eastward effect).

Even if the fault is located in the highest mountainous range of peninsular Italy (the 


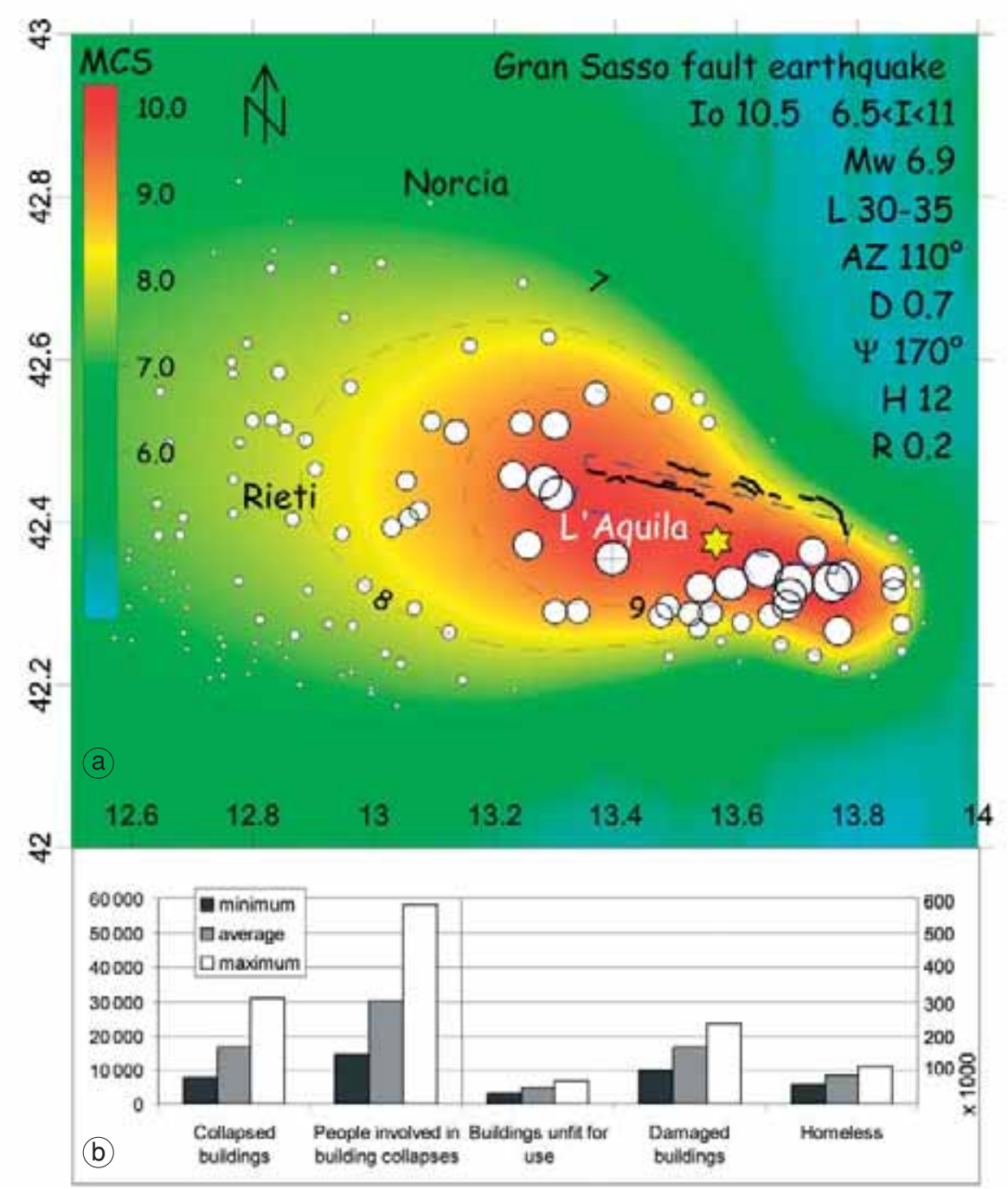

Fig. 10a,b. a) Image of the intensity datapoint distribution related to the activation of the entire Gran Sasso Range source, obtained through the application of the FaCES computer code (Galli et al., 2002b) with the reported fault parameters; the dashed rectangle defines the seismic source, while the dashed curves limit areas with the same intensity; the star marks the location of the epicenter used in the program routine. b) Analytical results of the damage scenario in terms of collapsed buildings, casualties, uninhabitable buildings, damaged buildings and homeless.

highest peak exceeds $2900 \mathrm{~m}$ a.s.l.), the derived earthquake scenario, also due to the large expected magnitude, is severe. It shows, indeed, an epicentral intensity of $I_{0} 10-11$ MCS and an area of heavy damage $(I \geq 8$, MCS) elongated more than $70 \mathrm{~km}$ in a WNW direction (fig. $10 \mathrm{a}, \mathrm{b})$. Figure 10b summarises the analytical results gathered through FaCES in terms of col- 
lapses, people involved in building collapses and damage. In particular, the town of L'Aquila would experience $I 10$ (MCS), with an estimated number of people involved in collapses ranging between 3000 and 11000 (3500-15000 in the entire region). Total collapsed buildings range between 7900 and 31 100, while damaged buildings are 99000-234000. This scenario suggests that, due to the location in the hangingwall of the Campo Imperatore Fault, the seismic risk can be considered very high for L'Aquila. The risk is not less serious than that related to the towns of Messina and Reggio Calabria in the area of the Messina Straits Fault, or to the towns and villages of the Fucino Basin in the Central Apennines before the occurrence of the 1908 (M 7.2) and 1915 (M 7) earthquakes, respectively. In short, the future rupture of the Campo Imperatore Fault will produce one of the most catastrophic earthquakes in modern Italian history.

\section{Conclusions}

The paleoseismological analysis in the Campo Imperatore area was performed to collect data on the Holocene activity of the fault bordering the Gran Sasso Range. The main results of our study are:

1) Number of events: three events have been identified along a secondary fault of the Campo Imperatore system: the youngest (E1) occurred after 3480-3400 years BP/2800-2700 years BP, a previous displacement (E2) occurred between 7155-7120/7035-6790 years BP and 5590-5565/ 5545-5475 years BP, the oldest event occurred slightly before 14120 years BP.

2) Recurrence interval: the time interval between the last two events ranges between 1995 and 6405 years (E2-E1 interval).

3) Minimum elapsed time: data on the elapsed time for the Campo Imperatore Fault are sparse, due to the lack of reliably datable units sealing the investigated faults; for this reason the elapsed time has been fixed in eight centuries, on the basis of the available historical data showing no evidence of earthquakes which may be related to the investigated faults and on considerations about the completeness of the seis- mic catalogues for the largest magnitude earthquakes.

4) Maximum expected magnitude: based on the length of the fault surficial expressions, and by means of the equations linking the surficial rupture length with the moment magnitude, the investigated fault may cause earthquakes with M 6.95 .

Considering the silent behaviour of the fault during at least the past eight centuries and the related high level of seismic hazard which may be associated with it, a damage scenario due to the activation of the Gran Sasso Range source has been produced. We used the FaCES code, specifically developed by the Seismic Survey of Italy for civil protection purposes. Results of the calculation showed that the activation of the mentioned source may be responsible for the collapse of 790031100 buildings and the damage of 99000234000 buildings. The obtained results indicate that although the fault is located in a sparsely inhabited area (high mountainous environment), its activation may be responsible for destructive effects in plain areas located up to $20 \mathrm{~km}$ far from the fault surficial expressions, where villages and towns are built. This substantially means that (beside a high level of hazard related to the silent state of the faults) a high seismic risk level can be associated with the entire region affected by the Gran Sasso Range source. Available data and related implications therefore define a quite vast area of Central Italy to which preventive activities should be devoted more than to other Italian tectonically active regions which experienced strong earthquakes during the 2nd millennium A.D.

\section{Acknowledgements}

A. Cittadini (CNR, Istituto di Geologia Ambientale e Geoingegneria, Roma) helped us in the fieldwork. We are grateful to C. Giraudi (ENEA-Casaccia, Roma) for the discussions about the chronological framework of the Late Pleistocene-Holocene continental stratigraphy and to G. Di Pasquale and G. Orsini (Servizio Sismico Nazionale, Roma) for the update of 
FaCES and the discussions about the damage scenarios.

\section{REFERENCES}

Asioli, A., F. Trincardi, J.J. Lowe, D. Ariztegui, L. LANGONE and F. OLDFIELD (2001): Sub-millennial scale climatic oscillations in the Central Adriatic during the Lateglacial: palaeoceanographic implications, Q. Sci. Rev., 20, 1201-1221.

Barchi, M., F. Galadini, G. Lavecchia, P. Messina, A.M. Michetti, L. Peruzza, A. Pizzi, E. Tondi and E. VITTORI (Editors) (2000): Sintesi delle conoscenze sulle faglie attive in Italia Centrale: parametrizzazione ai fini della caratterizzazione della pericolosità sismica, GNDT, Gruppo Nazionale per la Difesa dai Terremoti, Roma, spec. publ., pp. 62.

Boschi, E., G. Ferrari., P. Gasperini, E. Guidoboni, G. SMriglio and G. VAlensise (Editors) (1995): Catalogo dei Forti Terremoti in Italia dal 461 a.C. al 1980 (ING, Roma - SGA, Bologna), vol. 1, pp. 974.

Boschi, E., E. Guidoboni, G. Ferrari, G. VAlensise and P. GASPERINI (Editors) (1997): Catalogo dei Forti Terremoti in Italia dal 461 a.C. al 1990 (ING, Roma SGA, Bologna), pp. 644.

Boschi, E., E. Guidoboni, G. Ferrari, D. Mariotti, G. VAlEnsise and P. GasperinI (Editors) (2000): Catalogue of strong Italian earthquakes from 461 B.C. to 1997, Ann. Geofis., 43 (4), 609-868.

Camassi, R. and M. StuCCHI (1997): NT4.1, a Parametric Catalogue of Damaging Earthquakes in the Italian Area (Release NT4.1.1), http://emidius.mi.ingv.it/NT/ CONSNT.html.

Carrara, C., G. Dai Pra and C. Giraudi (1995): Lineamenti di tettonica plio-quaternaria dell'area, in Lazio Meridionale, Sintesi delle Ricerche Geologiche Multidisciplinari, ENEA Dipartimento Ambiente, Roma, 151-155.

Carraro, F. and M. Giardino (1992): Geological evidence of recent fault evolution. Examples from Campo Imperatore (L'Aquila-Central Apennines), Il Ouaternario, 5, 181-200.

Cavinato, G.P. (1993): Recent tectonic evolution of the Quaternary deposits of the Rieti basin (Central Apennines, Italy): southern part, Geol. Rom., 29, 411-434.

CNR-PFG (1987): Neotectonic map of Italy, Quad. Ric. Sci., 4 (114)

D'Addezio, G., E. Masana and D. Pantosti (2001): The Holocene paleoseismicity of the Aremogna-Cinque Miglia Fault (Central Italy), J. Seismol., 5, 181-205.

D'Agostino, N., J.A. Jackson, F. Dramis and R. FuNICIELLO (2001): Interactions between mantle upwelling, drainage evolution and active normal faulting: an example from the Central Apennines (Italy), Geophys. J. Int., 147, 475-497.

Di Pasouale, G., G. Orsini, A. Pugliese and R.W. Romeo (1998): Damage scenario from future earthquakes, in Proceedings of the 11th European Conference on Earthquake Engineering, Paris, September 6-11, 1998, Balkema, Rotterdam, edited by P. BISCH, P. LABBÉ and A. PECKER, 528-539.
FrezzotTi, M. and C. GiRAudi (1989): Evoluzione geologica tardo-pleistocenica ed olocenica del Piano di Aremogna (Roccaraso-Abruzzo): implicazioni climatiche e tettoniche, Mem. Soc. Geol. It., 42, 5-19.

FrezzotTi, M. and C. GIRAUdi (1990): Sedimenti eolici tardopleistocenici ed olocenici nell'Appennino Centrale, Mem. Soc. Geol. It., 45, 883-886.

Frezzotti, M. and C. Giraudi (1992): Evoluzione geologica tardo-pleistocenica ed olocenica del conoide complesso di Valle Majelama (Massiccio del Velino, Abruzzo), Il Quaternario, 5, 33-50.

FrezzotTI, M. and B. NARCISI (1989): Identificazione di un andosuolo, possibile livello guida per la cronostratigrafia olocenica dell'Appennino Centrale, Mem. Soc. Geol. It., 42, 351-358.

FrezzotTI, M. and B. NARCISI (1996): Late Quaternary tephra-derived paleosols in Central Italy's carbonate Apennine Range: stratigraphical and paleoclimatological implications, Quat. Int., 34-36, 147-153.

Galadini, F. and P. Messina (1994): Plio-Quaternary tectonics of the Fucino Basin and surrounding areas (Central Italy), G. Geol., 56, 73-99.

Galadini, F and P. Galli (1999): The Holocene paleoearthquakes on the 1915 Avezzano earthquake faults (Central Italy): implications for active tectonics in Central Apennines, Tectonophysics, 308, 143-170.

Galadini, F. and P. Galli (2000): Active tectonics in the Central Apennines (Italy) - input data for seismic hazard assessment, Nat. Haz., 22, 225-270.

Galadini, F. and P. Galli (2001): Archaeoseismology in Italy: case studies and implications on long-term seismicity, J. Earthquake Eng., 5, 35-68.

Galadini, F., P. Galli, I. Leschiutta, G. Monachesi and M. STUCCHI (1999): Active tectonics and seismicity in the area of the 1997 earthquake sequence in Central Italy: a short review, J. Seismol., 3, 167-175.

Galli, P., F. Galadini, M. Moro and C. Giraudi (2002a): New paleoseismological data from the Gran Sasso d'Italia area (Central Apennines), Geophys. Res. Lett., 29 (7), 10.1029/2001GL013292, 38.1-38.4.

Galli, P., G. Orsini, V. Bosi, G. Di Pasouale and F GALADINI (2002b): Testing damage scenarios. From historical earthquakes to silent active faults, in 27th General Assembly of the European Geophysical Society, April 21-26 2002, Geophys. Res. Abs., 4, EGS02-A-03979.

GIRAUDI, C. (1994): Elementi di geologia del Quaternario della Piana di Campo Imperatore (Gran Sasso d'Italia), Atti Tic. Sci. Terra, spec. ser., 2, 137-143.

GIRAUDI, C. (1995): Sedimenti eolici, variazioni climatiche ed influenza antropica: considerazioni su alcune piane intermontane dell'Appennino Abruzzese, Il Quaternario, $8,211-216$.

GIRAUDI, C. (1997): Le oscillazioni tardo-pleistoceniche ed oloceniche del lago effimero del Piano di Pezza (Abruzzo-Italia Centrale), Il Quaternario, 10, 191-200.

GIRAUDI, C. (1998a): Late Pleistocene and Holocene lake level variations in Fucino Lake (Abruzzo - Central Italy) inferred from geological, archaeological and historical data, in ESF Workshop Palaeohydrology as Reflected in Lake-Level Changes as Climatic Evidence for Holocene Times, Paläoklimaforschung, 25, 1-17. 
GIRAUDI, C. (1998b): I laghi effimeri tardopleistocenici e olocenici di Campo Imperatore e del Massiccio del Gran Sasso d'Italia (Abruzzo - Italia Centrale), Il Quaternario, 11, 217-225.

Giraudi, C. and M. FrezzotTi (1995): Paleoseismicity in the Gran Sasso Massif (Abruzzo, Central Italy), Quat. Int., 25, 81-93.

GiRAudi, C. and M. FrezzotTI (1997): Late Pleistocene glacial events in the Central Apennines, Italy, Quat. Res. 48, 280-290.

Magri, G. and D. Molin (1984): Il terremoto del dicembre 1456 nell'Appennino Centro-Meridionale, ENEA report $R T / A M B, 8(83)$, pp. 180.

Molin, D., F. Galadini, P. Galli, L. Mucci and A. Ross (1999): Sismicità della zona del Fucino, in 13 Gennaio 1915, il Terremoto nella Marsica, edited by S. Castenetto and F. Galadini, Servizio Sismico Nazionale and CNR Istituto di Ricerca sulla Tettonica Recente, Roma, 249-271.

MONACHESI, G. and M. STUCCHI (1998): DOM 4.1 an Intensity Database of Damaging Earthquakes in the Italian Area, http://emidius.mi.ingv.it/DOM/home.html.

Pantosti, D., G. D'Addezio and F.R. Cinti (1996) Paleoseismicity of the Ovindoli-Pezza Fault, Central Apennines, Italy: a history including a large, previously unrecorded earthquake in the Middle Ages (860-1300 A.D.), J. Geophys. Res., 101, 5937-5959.

Patacca, E., R. SARtori and P. Scandone (1990): Tyrrhenian Basin and Apenninic arcs: kinematic relations since Late Tortonian times, Mem. Soc. Geol. It., 45, 425-451.

Peruzza, L. and B. PACE (2002): Sensitivity analysis for seismic source characteristics to probabilistic seismic hazard assessment in Central Apennines (Abruzzo area), Boll. Geofis. Teor. Appl., 43, 79-100.

Siani, G., M. Paterne, E. Michel, R. Sulpizio, A. Sbrana, M. ARNOLD and G. HAdDAD (2001): Mediterranenan Sea surface radiocarbon reservoir age changes since the Last Glacial Maximum, Science, 294, 1917-1920.

StUCCHI, M. and P. AlbinI (2000): Quanti terremoti distruttivi abbiamo perso nell'ultimo millennio? Spunti per la definizione di un approccio storico alla valutazione della completezza, in Le Ricerche del GNDT nel Campo della Pericolosità Sismica (1996-1999), edited by F. Galadini, C. Meletti and A. Rebez (GNDT, Gruppo Nazionale per la Difesa dai Terremoti, Roma), 333-343.

Stuiver, M., P.J. Reimer, E. BARd, J.W. BeCK, G.S. BurR, K.A. Hughen, B. Kromer, G. McCormac, J. van der Plicht and M. SPURK (1998): INTCAL98 Radiocarbon Age Calibration, 24 000-0 cal BP, Radiocarbon, 40, 1041-1084.

Valensise, G. and D. Pantosti (Editors) (2001): Database of potential sources for earthquakes larger than $M 5.5$ in Italy, version 2.0, Ann. Geofis., suppl. 44 (4), 797-964.

Wells, D.L. and K.J. COPPERSMITH (1994): New empirical relationships among magnitude, rupture length, rupture width, rupture area, and surface displacement, Seismol. Soc. Am. Bull., 84, 974-1002.

Working Group CPTI (1999): Catalogo Parametrico dei Terremoti Italiani (ING, GNDT, SGA, SSN, Bologna), pp. 92.

ZolitschKA, B. and J.F.W. NegENDANK (1996): Sedimentology, dating and palaeoclimatic interpretation of a 76.3 ka record from Lago Grande di Monticchio, Southern Italy, Quat. Sci. Rev., 15, 101-112. 
